\title{
Editorial
}

\section{Worldwide Trends in Agronomy Research: Bibliometric Studies}

\author{
Esther Salmerón-Manzano $^{1}$ (D) and Francisco Manzano-Agugliaro ${ }^{2, *(\mathbb{D})}$ \\ 1 Faculty of Law, Universidad Internacional de La Rioja (UNIR), Av. de la Paz, 137, 26006 Logroño, Spain; \\ esther.salmeron@unir.net \\ 2 Department of Engineering, CEIA3, University of Almeria, 04120 Almeria, Spain \\ * Correspondence: fmanzano@ual.es; Tel.: +34-950-015-346; Fax: +34-950-015-491
}

check for updates

Citation: Salmerón-Manzano, E.; Manzano-Agugliaro, F. Worldwide Trends in Agronomy Research: Bibliometric Studies. Agronomy 2021, 11, 1993. https://doi.org/10.3390/ agronomy11101993

Received: 10 September 2021 Accepted: 24 September 2021 Published: 1 October 2021

Publisher's Note: MDPI stays neutral with regard to jurisdictional claims in published maps and institutional affiliations.

Copyright: (c) 2021 by the authors. Licensee MDPI, Basel, Switzerland. This article is an open access article distributed under the terms and conditions of the Creative Commons Attribution (CC BY) license (https:// creativecommons.org/licenses/by/ $4.0 /)$.

\begin{abstract}
Agriculture has the large challenge of providing food for a continuously growing world population, while natural resources remain the same. This great challenge is certainly supported in the future by Agronomy, which brings together practical knowledge and scientifically based techniques and applies them to agricultural productivity. Research in agronomy at a global level must reflect global interests, while considering the particular conditions of each country or region. One of the main objectives of this Special Issue is to contribute studies that help to identify the global research trends in agronomy, especially if they have an approach related to sustainability.
\end{abstract}

Keywords: agronomy; patents; scopus; sustainability; precision agriculture; coffee; ozone; environment; health; agroforestry; bibliometrics; berry growers; artificial intelligence; agriculture; robots; farming automation; economy; irrigation

\section{Introduction}

Agriculture is the world's most pressing and responsible sector, given that seven billion people must eat every day. To achieve this, there are the following three priority issues: health, variety, and quantity. Agriculture, therefore, is the cultivation of land or the production of crops from the soil, but its main science of study is agronomy. Agronomy can be understood as the field of science that oversees organizing the knowledge of various applied sciences, focused on enhancing the quality of production processes and the transformation of agricultural products.

Globally, food security is at risk, and for this reason, agronomy must achieve agricultural sustainability on Earth. In summary, Agronomy should contribute to improve the efficiency in the use of resources for food production.

One of the main objectives of this Special Issue is to contribute studies that help to identify the global research trends in agronomy, especially if they have an approach related to sustainability. Therefore, articles reviewing this state of the art in any of these issues, bibliometric or scientometric studies, and research articles with a global perspective are welcome. These studies are recommended to identify the research trends in each scientific field related to agronomy and, if possible, identify the open challenges in that particular field of study.

\section{Publications Statistics}

The summary of the call for papers for this Special Issue on the 12 manuscripts submitted is as follows: three rejected (25\%) and nine published (75\%).

The submitted manuscripts come from seven countries and are summarized in Table 1. For this statistic, only the first affiliation of the authors has been considered, in which it gives us the opportunity to observe 37 authors from 7 countries. Note that it is common for a manuscript to be signed by more than one author and for authors to belong to different affiliations. The average number of authors per published manuscript in this Special Issue was four authors. 
Table 1. Authors' countries: statistics.

\begin{tabular}{cc}
\hline Country & Authors \\
\hline Spain & 18 \\
Mexico & 1 \\
Honduras & 1 \\
Brazil & 4 \\
Chile & 4 \\
Italy & 2 \\
Greece & 7 \\
Total & 37 \\
\hline
\end{tabular}

\section{Authors' Affiliation}

There are 12 different affiliations of the authors. Note that only the first affiliation per author has been considered. Table 2 summarizes the authors and their first affiliations.

Table 2. Authors' affiliation: statistics.

\begin{tabular}{|c|c|c|}
\hline Author & First Affiliation & References \\
\hline Ochoa-Noriega, C.A. & University of Almeria & {$[1]$} \\
\hline Aznar-Sánchez, J.A. & University of Almeria & {$[1,2]$} \\
\hline Velasco-Muñoz, J.F. & University of Almeria & {$[1,2]$} \\
\hline Álvarez-Bejar, A. & National Autonomous University of México & [1] \\
\hline Mesa-Vázquez, E. & University of Almeria & [2] \\
\hline López-Felices, B. & University of Almeria & [2] \\
\hline Ruiz-Real, J.L. & University of Almeria & [3] \\
\hline Uribe-Toril, J. & University of Almeria & [3] \\
\hline Torres Arriaza, J.A. & University of Almeria & [3] \\
\hline de Pablo Valenciano J. A. & University of Almeria & [3] \\
\hline Cascajares, $\mathrm{M}$ & University of Almeria & [4] \\
\hline Alcayde, A. & University of Almeria & {$[4]$} \\
\hline Salmerón-Manzano, E. & Universidad Internacional de La Rioja (UNIR) & [4] \\
\hline Manzano-Agugliaro, F. & University of Almeria & [4] \\
\hline Borrero, J.D. & University of Huelva & [5] \\
\hline Zabalo, A. & University of Huelva & [5] \\
\hline Madrid-Casaca, $\mathrm{H}$. & Universidad Nacional Autónoma de Honduras & [6] \\
\hline Salazar-Sepúlveda, G. & $\begin{array}{c}\text { Universidad Católica de la Santísima } \\
\text { Concepción }\end{array}$ & [6] \\
\hline Contreras-Barraza, $\mathrm{N}$. & Universidad Andres Bello & [6] \\
\hline Gil-Marín, M. & Universidad Autónoma de Chile & [6] \\
\hline Vega-Muñoz, A. & Universidad Autónoma de Chile & {$[6]$} \\
\hline Jimenez-Montenegro, L.; & Universidad Politécnica de Madrid & [7] \\
\hline Lopez-Fernandez, M.; & Universidad Politécnica de Madrid & [7] \\
\hline Gimenez, E. & Universidad Politécnica de Madrid & [7] \\
\hline Santana, L.S. & Federal University of Lavras & [8] \\
\hline Ferraz, G.A.e.S. & Federal University of Lavras & [8] \\
\hline Teodoro, A.J.d.S. & Federal University of Lavras & [8] \\
\hline Santana, M.S. & Federal University of Lavras & [8] \\
\hline Rossi, G. & University of Florence & {$[8]$} \\
\hline Palchetti, E. & University of Florence & [8] \\
\hline Lytridis, C. & International Hellenic University (IHU) & [9] \\
\hline Kaburlasos, V.G. & International Hellenic University (IHU) & [9] \\
\hline Pachidis, T. & International Hellenic University (IHU) & [9] \\
\hline Manios, M. & International Hellenic University (IHU) & [9] \\
\hline Vrochidou, E. & International Hellenic University (IHU) & [9] \\
\hline Kalampokas, T. & International Hellenic University (IHU) & [9] \\
\hline Chatzistamatis, S. & International Hellenic University (IHU) & [9] \\
\hline
\end{tabular}




\section{Topics}

Table 3 summarizes the research conducted by the authors on this Special Issue, by identifying the areas to which they report. It was noted that they have been grouped into the following five main lines of research: Crops, Technologies, Water and Environment, Plant response, and Bibliometry.

Table 3. Topics for Worldwide Trends in Agronomy Research: Bibliometric Studies.

\begin{tabular}{ccc}
\hline Bibliometric Studies & Number of Manuscripts & References \\
\hline Water and Environment & 2 & {$[1,2]$} \\
Technologies & 2 & {$[3,9]$} \\
Bibliometry & 1 & {$[4]$} \\
Crops & 3 & {$[5,6,8]$} \\
Plant response & 1 & {$[7]$} \\
\hline
\end{tabular}

Author Contributions: E.S.-M. and F.M.-A. all made equal contributions to this article. All authors have read and agreed to the published version of the manuscript.

Funding: This research received no external funding.

Institutional Review Board Statement: Not applicable.

Informed Consent Statement: Not applicable.

Data Availability Statement: Not applicable.

Acknowledgments: The authors would like to thank to the CIAIMBITAL (University of Almeria, CeiA3) for its support.

Conflicts of Interest: The authors declare no conflict of interest.

\section{References}

1. Ochoa-Noriega, C.A.; Aznar-Sánchez, J.A.; Velasco-Muñoz, J.F.; Álvarez-Bejar, A. The Use of Water in Agriculture in Mexico and Its Sustainable Management: A Bibliometric Review. Agronomy 2020, 10, 1957. [CrossRef]

2. Mesa-Vázquez, E.; Velasco-Muñoz, J.F.; Aznar-Sánchez, J.A.; López-Felices, B. Experimental Economics in Agriculture: A Review of Worldwide Research. Agronomy 2021, 11, 1566. [CrossRef]

3. Ruiz-Real, J.L.; Uribe-Toril, J.; Torres Arriaza, J.A.; de Pablo Valenciano, J.A. Look at the Past, Present and Future Research Trends of Artificial Intelligence in Agriculture. Agronomy 2020, 10, 1839. [CrossRef]

4. Cascajares, M.; Alcayde, A.; Salmerón-Manzano, E.; Manzano-Agugliaro, F. Transfer of Agricultural and Biological Sciences Research to Patents: The Case of EU-27. Agronomy 2021, 11, 252. [CrossRef]

5. Borrero, J.D.; Zabalo, A. Identification and Analysis of Strawberries' Consumer Opinions on Twitter for Marketing Purposes. Agronomy 2021, 11, 809. [CrossRef]

6. Madrid-Casaca, H.; Salazar-Sepúlveda, G.; Contreras-Barraza, N.; Gil-Marín, M.; Vega-Muñoz, A. Global Trends in Coffee Agronomy Research. Agronomy 2021, 11, 1471. [CrossRef]

7. Jimenez-Montenegro, L.; Lopez-Fernandez, M.; Gimenez, E. Worldwide Research on the Ozone Influence in Plants. Agronomy 2021, 11, 1504. [CrossRef]

8. Santana, L.S.; Ferraz, G.A.e.S.; Teodoro, A.J.d.S.; Santana, M.S.; Rossi, G.; Palchetti, E. Advances in Precision Coffee Growing Research: A Bibliometric Review. Agronomy 2021, 11, 1557. [CrossRef]

9. Lytridis, C.; Kaburlasos, V.G.; Pachidis, T.; Manios, M.; Vrochidou, E.; Kalampokas, T.; Chatzistamatis, S. An Overview of Cooperative Robotics in Agriculture. Agronomy 2021, 11, 1818. [CrossRef] 